The Geneva Papers on Risk and Insurance, 20 (No. 77, October 1995) 517-523

\title{
The Promotion of Insurance Economics within Universities and Learning Institutions
}

\author{
by Orio Giarini *
}

Promotion of the teaching of insurance economics was among the very earliest of the Geneva Association's activities, and from the outset the Association's goals with this initiative have been:

- To stimulate an adequate level of insurance economics teaching in the insurance world.

- To prepare the ground for the final objective whereby one day students of economics in higher institutions the world over would consider it essential that their studies curricula provide a sound grounding in insurance and risk management matters.

There follows a step-by-step description of the strategy we devised to achieve this objective and of the implementation and consolidation of that strategy over time.

\section{First, we sought to bring together and stimulate exchange among those teaching insur-} ance economics in institutions of higher education in Europe and elsewhere

As early as 1973, we started to build up a repertoire of professors in higher institutions in Europe teaching insurance economics. We were able to bring together in Geneva eight such professors, representing five different countries, who had never met before. This was the starting point for the "European Group of Risk and Insurance Economists".

In 1974, with our support, this group organised the first series of annual seminars which has continued until today. That first seminar was chaired by Prof. Raymond Barre.

The group now involves over 300 professors and teachers of insurance economics and related subjects in over 100 universities, not only in Europe but also in the United States and in other continents as well. At each seminar, attendance is limited to 30-35 participants. ${ }^{1}$

Information about the specific issues discussed at these meetings and their treatment can be found in our publications.

Before proceeding any further let us be clear about one thing: The teaching of insurance economics across Europe was not only widely scattered and frequently limited in scope, but highly diverse also, reflecting as it did the individual traditions of the countries wherein it was taught. Germany, for instance, since the beginning of the century, has had

\footnotetext{
* Secretary General, the Geneva Association.

1 For a list of these seminars, see page 268 of The Geneva Papers Nr. 68, July 1993.
} 
strong programmes within the universities, coordinated by the Verein für Versicherungswissenchaft, so that even today about $80 \%$ of the university higher-level teaching of insurance in Europe is still done in Germany. The focus of this teaching, it should be added, is micro-economic.

Moreover, in providing this type of teaching, German universities are doing a job which, in other countries, is often the responsibility of special educational institutions outside universities.

Even in a country with a great tradition of insurance like the United Kingdom, the teaching of insurance economics was for many years confined to just two chairs, one in London and the other in Nottingham. Today, supported by the British annual seminar of insurance economists which started about ten years ago, initiatives are spreading.

In France, a decisive step was recently taken by Prof. Denis Kessler, President of the French Federation of Insurance Companies, with the establishment of three very high-level insurance economics chairs and institutes in that country.

In Belgium, both the country's languages are represented in different institutions where frequently, sometimes with the help of the Insurance Federation, local professors have had an important part to play.

In Italy, initiatives, some of which have been running for several years now, have scattered widely over the national territory including Rome, Venice, Milan, Turin, Pisa, and Naples. Over the last two years, a more structured approach has been attempted at the Bocconi and the "Catholic" universities in Milan.

In Switzerland, insurance economics education, again at the micro-economic level, is concentrated at the University of St Gall. Elsewhere in Europe the teaching of insurance economics is sparse. Norway had a great tradition with Prof. Karl Borch in Bergen until he died. Now one of the most reputed teachers in the Scandinavian countries is Prof. Göran Skogh of the Lund University.

By contrast, in the United States, an association of university teachers of insurance economics has existed for several decades. It brings together a membership of about 800 professors, with whom we have established many contacts and had several occasions to collaborate.

In pursuing our promotion strategy, it should be noted, we have not limited ourselves to professors teaching explicitly insurance economics, but have extended our network to include those who have increasing occasions to address issues directly or indirectly related to insurance economics (health economics, social security and savings issues, moral hazard and public policy, decision strategies for catastrophic risks and the environment, etc.).

2. Our second step was to start a series of studies with the aim of compiling a catalogue of teaching in risk and insurance economics. Our purpose here was to:

- Stimulate those already active in this field; and

- Provide concrete examples that could be followed by other professors and teachers in Europe and around the world. Such studies include examples of teaching programmes, bibliographies and generally information that would be of assistance to new teachers. 
The first study was undertaken in 1976 by Prof. Henri Loubergé and was published in French. An English version ("The Teaching of Risk and Insurance Economics in Europe") appeared in The Geneva Papers Nr. 4 in January 1977. It should be stressed that many ideas and suggestions contained in this work are in essence as relevant today as they were when Prof. Loubergé, at the time Assistant Secretary General of the Geneva Association, in preparing his PhD thesis, began work on what was to become a key and remarkably successful book on the teaching of insurance economics.

As a result of subsequent collaboration between Prof. Loubergé and $\mathrm{H}$. Kaplanek, the study was then updated by Prof. Haller of the University of St Gall and published in German in 1978 in the form of a 260-page book entitled: "Versicherungs und Risiko Wirtschaftslehre in Europa". A third revision in English was produced at the University of Nottingham in 1980 (by Penny Stark, 260 pages) under the title: "The Teaching of Risk and Insurance Economics and Risk Management in Europe".

A further updating was made in French in 1987 and published in the Etudes et Dossiers Nr. 117. Under the supervision of Prof. S.P.L. Kennedy, the study was then further researched by the City University Business School in London and put on to a databank where it is still regularly updated (see Etudes et Dossiers Nr. 177, May 1993).

In 1992, through a survey done at the Cologne University, our catalogue (see Etudes et Dossiers Nr. 164) was extended to Eastern Europe.

We are now preparing, with the help of Prof. Denis Kessler and with contributions from researchers linked to the databank at the City University Business School, a complete revision and reassessment of this study.

\section{Publications, prizes and other back-up initiatives for the promotion of insurance economics} which:

Our activities in this field have been backed-up by a wide range of publications, among

- In 1976, following the suggestion of Prof. Raymond Barre, The Geneva Papers on Risk and Insurance were launched with the idea of producing an academic series like the "Princeton Papers". However, due to the increasing availability of research reports and other contributions, The Geneva Papers soon became the quartely magazine they have since remained.

- From almost the beginning, a special annual edition of the Papers devoted to insurance economics at the academic level was published, in order to provide university professors an opportunity to disseminate their ideas in print.

- In 1990, The Geneva Papers on Risk and Insurance - Theory were created, again under the leadership of Prof. Henri Loubergé, so as to be able to concentrate into a special series academic papers whose main purpose was to promote the diffusion of insurance economics to higher educational institutions. Since then, the original Geneva Papers have been able to concentrate on more practical issues (Issues and Practice series). The Theory series is published by Kluwer, twice yearly.

The circulation of the original Geneva Papers is about 2200 copies, that of the Theory series is about 800 . 
In addition, for the last 15 years, a Newsletter of the European Group of Risk and Insurance Economists has been published once or twice a year, in order to stimulate contacts and exchange of information in the academic field. Today, this Newsletter has a circulation of about 1100 mailings worldwide.

From the outset, the Association's activities have included provision of one or two scholarships per year to stimulate the development of $\mathrm{PhD}$ theses in insurance economics, and an "Ernst Meyer Prize" 2 has been awarded yearly since 1974 for PhD theses in insurance economics.

Since 1989, on the occasion of the seminars of the European Group of Risk and Insurance Economists, the practice of a "Geneva Risk Economics Lecture" has been established. ${ }^{3}$

\section{Upgrading insurance economics}

When we first became active in this field, although we were able to count on many scholars of quality, it was obvious both in Europe and in the United States, that, as far as the top circle of the world economics' community were concerned, insurance economics was still considered a secondary branch. There are several historical reasons for this situation which we have described in various papers, as also in the introduction to The Teaching of Risk and Insurance Economics in Europe, in The Geneva Papers Nr. 4.

We needed therefore to penetrate the citadel surrounding the world's top economists and to bring home to them the message that insurance economics was, as the Austrians say, "hoffähig", i.e. a discipline worthy of interest and consideration at the very highest level.

Our strategy has been to set up a series of "Annual Lectures" to which we have invited the world's best known economists to speak on and debate subjects close to their own specialities with, directly or indirectly, a bearing on insurance problems.

The first lecture in this series was given by Kenneth Arrow, a Nobel Prize in economics and wellknown for his theories on health economics which have many points in common with the topic of uncertainty in insurance. The lecture was given at the London School of Economics in 1977 and the series has continued ever since, with at least one lecture per year, in different parts of Europe, and occasionally in the United States.

These lectures are backed by a panel of two or three discussants thus enlarging the circle to include other reputed economics. Their contributions together with the lecture are published in The Geneva Papers.

One of the pratical effects of these lectures has been that, when we came to establish a Scientific Advisory Committee for the Geneva Papers on Risk and Insurance Theory, we were able to count on contributions from some of the best known economists in the United States and Europe. ${ }^{4}$

\footnotetext{
${ }^{2}$ The winners are listed on page 272 of The Geneva Papers Nr. 68, July 1993.

${ }^{3}$ The list of these lectures is listed on page 269 of The Geneva Papers Nr. 68, July 1993.

${ }^{4}$ The list of Annual Lectures appears on page 267 of Geneva Papers Nr. 68. An updated version of this list is provided in the Newsletter of the European Group of Risk and Insurance Economists.
} 


\section{Bringing the teaching of risk and insurance economics to the attention of lawyers and engineers}

5.1. Over a decade ago, the European Association on Law and Economics (EALE) was founded with the assistance of some of the participants to the seminar of the European Group of Risk and Insurance Economists.

The EALE brings together university professors teaching in areas where law and economics are closely interrelated. In most of these areas, insurance-related problems and issues will be encountered such as, for example, liability insurance and regulation, environmental policies, catastrophic risks, etc. This Association is similar to one of the same kind in the United States.

Since 1985, we have organised with this Association a biannual seminar on law and economics which, on each occasion, is attended by about 25 to 30 experts from Europe and the United States.

Special issues of The Geneva Papers are published with papers presented on these occasions.

EALE, we should add, is now a flourishing Association with over 200 members in Europe.

5.2. Starting with industrial risks and related issues, we organised in 1983 our first survey, undertaken by the Centre for Insurance Research in London, on "Risk and Insurance Economics Education for Engineers".

This first report was discussed at the first M.O.R.E. (Management of Risk and Engineering) meeting in London in the same year with a contribution by Prof. Gordon Dickson, who is now Managing Director of the Institute of Risk Management in London. Ever since, MORE meetings have been organised every year, focussing on research into technological risks. Meanwhile,the education programme has continued and has produced further specific reports on such topics as:

- "The Teaching of Risk and Insurance Economics for Engineers in the UK, the Scandinavian Countries and Holland"; the definitive version of this research by D. Sutherland was published in the Etudes et Dossiers Nr. 79 and 80 (April and May 1984).

- "Risk Management and Insurance" (Risk Management und Versicherungslehre)" with a main focus on Germany, by Wolf-Rüdiger Heilmann of the University of Karlsruhe, published in the Etudes et Dossiers Nr. 128 (November 1988).

- Within this series also, a study was done in 1993 on "Teaching Risk Management for Engineers in Italy", in collaboration with the CINEAS of the Milan Polytechnicum, and was published in the Etudes et Dossiers Nr. 176 (April 1993).

\section{Risk, insurance and the service economy}

As described in sections 1 to 4 of this report, we have attempted to sollicit the personal views of economists and the views of the institutions they represent and to interpret those views according to what is called "neo-classical economics". We have then attempted to identify and develop with them those areas and issues where consideration of insurance and insurance mechanisms becomes inevitable. 
We have, at the same time, approached this subject from a rather different angle which relates to current debate and research on the fundamental economic changes brought about by the new role of services. This approach views the modern economy as being essentially based on services (given that modern manufacturing industry is essentially about producing, distributing and managing services, rather than products). In this scenario, as a typical service, insurance becomes a key reference. But more than this, we have tried to foster acceptance of the following idea: the service economy is based on a system of price fixing which increasingly involves making hypotheses about future events or costs in the utilisation of products and services. In this approach, then, we are applying to the economy as a whole an economic logic (the inverted cycle of production) which is typical of insurance.

This line of initiative has been developed in the following ways:

- The setting up at Geneva University, by the Secretary General, of a course on service economics for economists.

- The organisation of a further network of economists and experts from different sectors interested in service activities: The first seminar convened by this network took place ten years ago and was named PROGRES (Programme of Research on the Economics of Services). A seminar in this series is now organised every year, its purpose being to confront insurance activities with other service activities.

- In addition, a PROGRES Bulletin is now regularly published and distributed to over 2400 people worldwide (the highest circulation of all our newsletters). One of the reasons for its success is of course the fact that we have long been pioneering interest in services, even before the GATT decided to include services within its negotiations. Today services are a well established and accepted focus of the new World Trade Organisation.

However it should be remembered that this service-based approach to the economy as a whole is still at its infancy and will probably take one more decade before becoming an established part of general economic thinking.

\section{Miscellaneous activities}

These core initiatives of our strategy to develop risk and insurance economics have also been enriched, over the last twenty years, by a whole series of research activities, publications and conferences on other major economic issues relating to insurance, such as:

- The Geneva Papers Nr. 66 contained a comprehensive introductory booklet on insurance economics which has been translated into Spanish and widely distributed in Latin America by the regional insurance secretariat (FIDES).

- A series of seminars and publications has been organised on the European Monetary System, the European Currency Unit (ECU) and its impact on insurance, mainly with the collaboration of Prof. Gerry Dickinson.

- A complete series of studies on the notion of productivity in economics and insurance was promoted and published in The Geneva Papers (under Prof. Denis Kessler' guidance).

- The Association also organised a special economic analysis of international organisations and their development in insurance activities, studying the case of MIGA, the "insurance" organisation of the World Bank, and many others.

- Applied strategic planning in insurance has been a theme which many of the threeyearly sessions, organised in London, with contributions by experts and academicians, have kept abreast of. 
- The economic question of the value of human life has also been examined on a couple of occasions, and has led to publication of a book.

- The Credit Insurance issue has been examined in detail and has led to the publication of an important book (by Prof. Henri Loubergé).

- The issue of environment and health has been dealt at several seminars and in various publications.

- Problems relating to social security, savings and the ageing of the population have been considered in detail and are part of a structured programme. ${ }^{5}$

- As far as methodology is concerned, during the first years of its existence, the Geneva Association devoted much attention to developing simulation models such as GIM (Geneva Insurance Model) and ASIR. ${ }^{6}$

All these study initiatives, as indeed the Geneva Association's entire research programme in these and other fields, are designed to be "food for thought" in stimulating the setting up of teaching programmes on contemporary key issues in risk and insurance economics.

\section{Conclusions}

We would like to draw attention to the following considerations:

- Over the last 22 years, we have set up a well-structured programme which is gradually helping to promote adequate teaching of risk and insurance economics across the entire world community of economists.

- We cannot, of course, claim as yet to be very close to the goal of introducing risk and insurance economics into the core-curriculum of economists' training the world over. We are confident however that this will happen, although not before one or even two decades have passed, which is the reason for our continuity and perseverance in this area.

- What we are in fact facing is a real cultural change that will require fundamental adaptation and an opening-up of new horizons in society, in particular, in learned society. One such new horizon, and a key one, would be opened-up by substituting the notion of general uncertainty for that of general certainty in the models we construct to assist us in our economic thinking.

- What matters and what justifies our activity and the motivation of a growing number of economists and experts is that we are advancing along an increasingly creative road towards constructive solutions both in practical and in theoretical terms. To be effectively involved in this type of endeavour at all, is truly a priviledge.

\footnotetext{
${ }^{5}$ In this connection, see the description from page 247 onwards of The Geneva Papers Nr. 68 and the newsletters on The Four Pillars.

${ }^{6}$ See the description in The Geneva Papers Nr. 68, from page 278 onwards.
} 